\title{
Review of proton- and oxide-ion-conducting perovskite materials for SOFC applications
}

1 Kavitha Karuppiah MTech

Senior Research Fellow, Functional Materials Laboratory, PSG Institute of Advanced Studies, Coimbatore, India
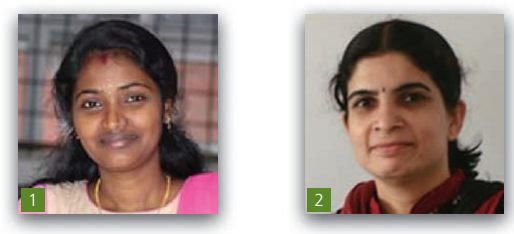

In this review, the essential use of perovskites and their structural properties associated with proton and oxide-ion conductivity are explained specifically for applications in solid oxide fuel cells (SOFCs), electrolyser cells and so on. The number of oxygen vacancies and their distribution in the crystal structure play a crucial role in perovskites, which exhibit good protonic and oxide-ion conductivity. Atmospheric stability at the operating temperature is another important factor that decides the long-term usage of the materials. Here the properties are summarised in terms of stability, proton defects, ordering and cation substitution. A basic understanding of all of these properties will give a direction to synthesis of compounds with desired proton and oxide-ion conductivity for applications in renewable and sustainable energy devices. A certain group of perovskite oxides, when prepared as nanostructures, is specifically used in fuel cell electrodes for improved performance. A few trends and highlights of current scientific advances in nanoperovskites for energy applications are discussed. The high stability of the proton conductor $\mathrm{Ba}_{3} \mathrm{Ca}_{1.18} \mathrm{Nb}_{1.82} \mathrm{O}_{8.73}$ and substitution of new dopants in this compound for SOFC devices are highlighted in this review.

\section{Notation}

$r_{\mathrm{A}} \quad$ ionic radius of the A-site cation

$r_{\mathrm{B}} \quad$ ionic radius of the B-site cation

$r_{\mathrm{O}} \quad$ ionic radius of the oxygen ion

$t$ tolerance factor

\section{Introduction}

The majority of the current energy systems that are mainly based on the combustion of fossil fuels cause many environmental problems such as air pollution, acid rain and greenhouse gas emissions. A significant amount of energy is also utilised for electricity generation and transportation, which is essential for daily life. ${ }^{1}$ Due to increased industrialisation, the demand for energy, over-utilisation of energy resources and carbon dioxide $\left(\mathrm{CO}_{2}\right)$ emission have increased. Inefficient production and distribution of energy affects all sectors of the global economy. Major technological developments result in increasing energy demand. The quest for solutions to the deepening energy crisis points towards the question of how energy can be used on earth more efficiently and how to keep the environment clean. All efforts to solve these problems should include both conservation of energy resources and decrease in carbon dioxide emission. ${ }^{1,2}$ In this review, the authors report the role of perovskite oxides as proton and oxide-ion conductors in energy applications.

\section{Perovskites}

The mineral perovskite was discovered by Gustav Rose in 1839 , and it was named after Russian mineralogist Lev Perovski. The name 'perovskite' was originally given to the mineral $\mathrm{CaTiO}_{3}$ (calcium titanate). ${ }^{3}$ Perovskite-type oxides are the materials with the general formula $\mathrm{ABO}_{3}$, with the larger A cation coordinated to 12 anions and the $\mathrm{B}$ cation occupying six coordinate sites, forming a network of corner-sharing $\mathrm{BO}_{6}$ octahedra, as shown in Figure 1. The larger $\mathrm{A}$ cations can be rare-earth elements alkaline earth or alkali ${ }^{4}$ - whereas the smaller B cations include transition metals. The ionic radii and valence of cations determine the distortions present in the crystal structure, which in turn are responsible for the chemical and physical properties of the materials. ${ }^{4}$ This type of perovskite oxide materials, due to their adaptability, are extensively studied and used for a wide range of applications. Materials with the perovskite structure are desirable due to their unique properties such as catalytic behaviour, ferroelectricity, thermoelectricity, magnetic properties, oxide-ion conduction and proton conduction ${ }^{5-8}$ that are useful in gas sensors, gas separation membranes, thermal barriers, solid oxide fuel cell (SOFC) electrolytes and so on. Moreover, materials with the perovskite structure, when compared to materials with other crystal arrangements, generally exhibit good stability. Appropriate selection of A and B cations, to maintain suitable defects such as 


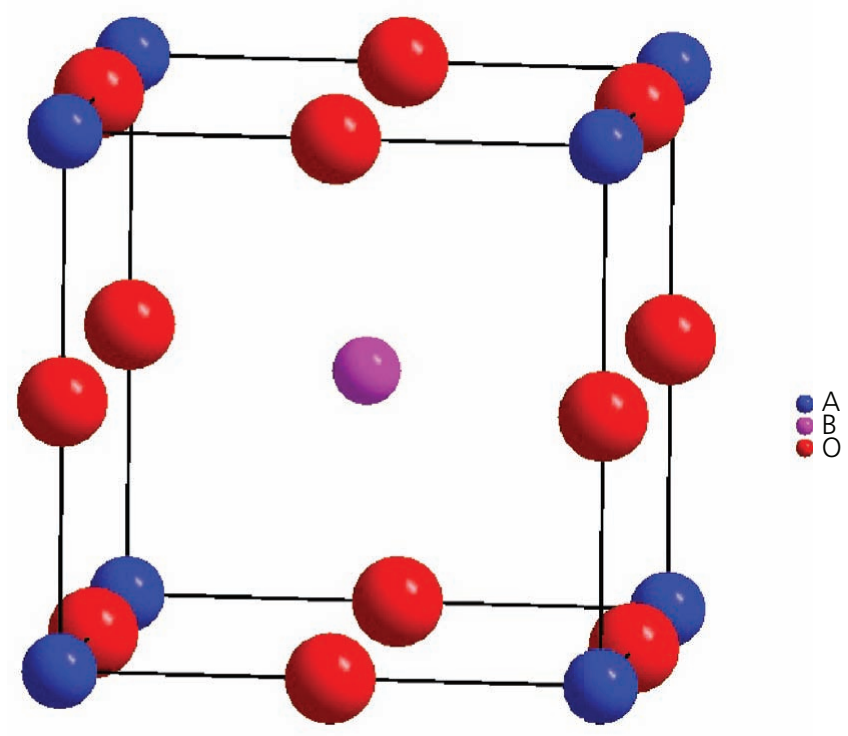

Figure 1. General cubic structure of the $\mathrm{ABO}_{3}$ perovskite oxides

oxygen vacancies and non-centrosymmetry, makes them suitable for many solid-state device applications.

\subsection{Stability of perovskites}

The stability of the perovskite structure is determined in terms of the Goldschmidt tolerance factor developed in the 1920s based on the following equation

1. $t=\frac{r_{\mathrm{A}}+r_{\mathrm{O}}}{2^{1 / 2}\left(r_{\mathrm{B}}+r_{\mathrm{O}}\right)}$

In the above equation $r_{\mathrm{A}}, r_{\mathrm{B}}$ and $r_{\mathrm{O}}$ are the ionic radii of the A-site cation, B-site cation and oxygen ion, respectively. The stable perovskite structure is expected to have $0.77 \leq t \leq 1 .{ }^{9,10}$ Tuning the $t$ value close to unity with appropriate choices of A and $\mathrm{B}$ cations results in high-symmetry crystal structures with a small unit cell volume. ${ }^{11}$ For a perfect cubic structure, the value of the tolerance factor is equal to $1(t=1)$. It is obtained by selecting the size of the A-site cation to be closer to that of the oxygen ion (1.40 $\AA$ ). In a perfect cubic perovskite structure, the B-O-B chains are linear with a bond angle of $180^{\circ}$. When the crystal structure varies from cubic to another symmetry, the bond angle of $\mathrm{B}-\mathrm{O}-\mathrm{B}$ chains will be reduced. For $t>1$, the hexagonal structures tend to be stable, ${ }^{9}$ whereas for $t<1$, the lattice structure changes from cubic to rhombohedral and then to orthorhombic. ${ }^{10,12}$ Figure 1 represents an A-cation-centred view of the basic cubic perovskite.

\subsection{Cation substitution in perovskites}

It is well known that the specific properties of perovskite materials are tailored by suitable cation substitution. Appropriate substitution of cation material helps in the enhancement of magnetism, electrical conductivity, surface area, mechanical strength and catalytic reactivity. ${ }^{10,13}$ The variations of such properties generally result from the B cations, but are tuned by the A-site cations. Factors such as the ionic radius of the A cation and its valence control stability and other properties. ${ }^{14}$ For example, when lower-valence dopants are substituted in the cationic site, oxygen vacancies are introduced within the perovskites, which further enhance specific properties such as ionic conductivity. ${ }^{10}$ Depending on the nature of the material, the dopant can drastically affect the band structure and hence the electronic properties can also be changed. The partial cation substitution in the A and B sites with divalent elements (calcium $(\mathrm{Ca})$, strontium $(\mathrm{Sr})$ and barium $(\mathrm{Ba})$ ) will result in significant changes on oxygen diffusion and the surface exchange coefficients of those perovskite materials which can be used in oxygen semi-permeable membranes. ${ }^{15}$ In perovskite-type oxide, the partial substitution at the A site with another metal cation strongly influences the catalytic activity due to the stabilisation of $\mathrm{B}$ cation oxidation states and the formation of structural defects. The structural defects are responsible for catalytic activity and oxygen mobility within the solid crystal lattice due to the non-stoichiometry created by the substitution. ${ }^{16}$ For example, the progressive substitution in the B-site position of iron (III) $\left(\mathrm{Fe}^{3+}\right.$ ) by nickel (II) $\left(\mathrm{Ni}^{2+}\right)$ in $\mathrm{La}_{0.6} \mathrm{Ca}_{0.4} \mathrm{Fe}_{1-x} \mathrm{Ni}_{x} \mathrm{O}_{3}$ entails the progressive formation of oxygen vacancies. The highest catalytic properties are found for the compound with more oxygen vacancies. ${ }^{16}$

Cation substitution also introduces oxygen vacancies into such perovskite oxides by enhancing the mixed (oxygen) ionic-electronic conductivity and reduction-oxidation (redox) properties, ${ }^{17}$ which are beneficial for applications in SOFCs, oxygen-permeable membranes, metal-air batteries and electrochemical water $\left(\mathrm{H}_{2} \mathrm{O}\right)$ splitting. ${ }^{18-21}$ In the type of perovskites explained in the next section, although perovskites are stoichiometric and chemically neutral, oxygen vacancies can be formed due to the insufficient oxygen atoms provided by the stoichiometric perovskite to occupy the available oxygen sites in the crystal structure. ${ }^{22}$

\subsection{Non-stoichiometric $\mathrm{A}_{3} \mathrm{~B}^{\prime} \mathrm{B}^{\prime \prime}{ }_{2} \mathrm{O}_{9}$ complex perovskite as proton and oxide-ion conductors}

Complex perovskites of type $\mathrm{A}_{3} \mathrm{~B}^{\prime} \mathrm{B}^{\prime \prime}{ }_{2} \mathrm{O}_{9}$, where $\mathrm{A}$ and $\mathrm{B}^{\prime}=$ alkaline-earth metal and $\mathrm{B}^{\prime \prime}=$ niobium $(\mathrm{Nb})$ and tantalum $(\mathrm{Ta})$, are found to have the interesting property of mixed proton and oxide-ion conductivity and were first observed in the early 1990s. ${ }^{22,23}$ This type of complex perovskite has a wide range of applications as electrolytes in fuel cells, electrolysers, batteries, sensors and so on. ${ }^{24-26}$ Several compositions of $\mathrm{A}_{3} \mathrm{~B}^{\prime} \mathrm{B}^{\prime \prime}{ }_{2} \mathrm{O}_{9}$-type complex perovskites have been extensively studied because of the possibility of creating effective negative charges by varying the ratio between $\mathrm{B}^{\prime}$ and $\mathrm{B}^{\prime \prime}$ ion concentrations. ${ }^{26}$ From the structural point of view, $\mathrm{A}_{3} \mathrm{~B}^{\prime} \mathrm{B}^{\prime \prime}{ }_{2} \mathrm{O}_{9}$ is different from the $\mathrm{ABO}_{3}$ perovskite structure: it contains a mutually compensating mixture of pentavalent and divalent cations in the B-site sublattice. ${ }^{22}$ The large valence difference makes the two $\mathrm{B}$ cations ordered. ${ }^{27}$ The variation in the ratio between $\mathrm{B}^{\prime}$ and $\mathrm{B}^{\prime \prime}$ ions makes the 
perovskite stoichiometric or non-stoichiometric. For example, the $\mathrm{Ba}_{3} \mathrm{Ca}_{1+x} \mathrm{Nb}_{2-x} \mathrm{O}_{9-3 x / 2}$ perovskite series has two types of ordering: $1: 1$ and $1: 2$, based on the ratio between $\mathrm{B}^{\prime}$ and $\mathrm{B}^{\prime \prime}$ ions. ${ }^{22,23,28,29}$ When $x=0$, the aforementioned composition becomes $\mathrm{Ba}_{3} \mathrm{Ca}_{1} \mathrm{Nb}_{2} \mathrm{O}_{9}$, in which calcium and niobium atoms are in the ratio 1:2. With this arrangement, the material has a crystal structure with trigonal symmetry with no structural oxygen vacancies. The calcium atoms are arranged in one layer and the niobium atoms in two layers along the $c$-axis of the trigonal unit cell as described earlier. ${ }^{19}$ When $x=0.5$, the composition becomes $\mathrm{Ba}_{3} \mathrm{Ca}_{1.5} \mathrm{Nb}_{1.5} \mathrm{O}_{8 \cdot 25}$, in which calcium and niobium atoms are in the ratio $1: 1$, having a crystal structure with cubic symmetry with two oxygen-deficient sites. This structure has alternate layers of calcium and niobium atoms along the body diagonal of the cubic unit cell. ${ }^{25,26}$ Later Nowick et al. ${ }^{23}$ and Norby ${ }^{24}$ studied various compositions of $\mathrm{Ba}_{3} \mathrm{Ca}_{1+x} \mathrm{Nb}_{2-x} \mathrm{O}_{9-3 x / 2}$ perovskite $(x=-0.03,0 \cdot 0,0.03,0 \cdot 09,0 \cdot 18,0.4$ and 0.36). For $x=$ -0.03 and 0.0 , the compound showed $1: 2$ ordering; $x=0.03$ showed both 1:1 and 1:2 ordering, and for $x=0.09$ and above, the compound showed 1:1 ordering. From this observation, it is revealed that introducing non-stoichiometry induces a 1:2 to $1: 1$ structural order transformation. ${ }^{26}$ These types of complex perovskites behave as proton conductors in wet atmospheres at lower temperatures and oxide-ion conductors in dry atmospheres at higher temperatures. ${ }^{29}$

\section{Proton conductivity in doped perovskites} Iwahara et al..$^{30}$ published the first report on proton conduction in perovskites in the 1980s. They studied cerates of barium $\left(\mathrm{BaCeO}_{3}\right)$ and strontium $\left(\mathrm{SrCeO}_{3}\right)$ systems and observed high levels of proton conductivity $\left(10^{2}-10^{-3} \mathrm{~S} / \mathrm{cm}, 600-1000^{\circ} \mathrm{C}\right) .{ }^{30}$ After 20 years of intense research, the perovskite-type cerates and zirconates have become well-known proton conductors. ${ }^{31-33}$ Later, other perovskite oxides were also found to show a good response against proton conduction. One of the best-known perovskite proton conductors is $\mathrm{Ba}_{3} \mathrm{Ca}_{1 \cdot 18} \mathrm{Nb}_{1.82} \mathrm{O}_{8.73}$ ( $\mathrm{BCN} 18$ ), which displays a combination of high proton mobility and relatively high proton concentration. This exhibits proton conductivities close to $10^{-3} \mathrm{~S} / \mathrm{cm}^{29}$ This compound is a result of introducing non-stoichiometry into the parent perovskite oxide to obtain desirable defects such as oxygen vacancies.

\subsection{Protonic defects in perovskites}

In perovskite oxides at moderate temperatures, the formation of protonic defects occurs by dissociative absorption of water, which requires the presence of oxide-ion vacancies $V_{\mathrm{O}}$. The vacancies are formed either intrinsically by varying the ratio of main constituents in the composition or extrinsically by acceptor doping. ${ }^{27}$ The oxygen vacancies formed incorporate the protons into the material as shown in Figure 2. When these materials are exposed to humid atmospheres, the water molecule in the gas phase dissociates into a hydroxide ion and a proton. ${ }^{34}$ The hydroxide ion sits on the oxide-ion vacancy and the protons occupy the interstitial sites of the perovskite lattice. This phenomenon is explained as follows

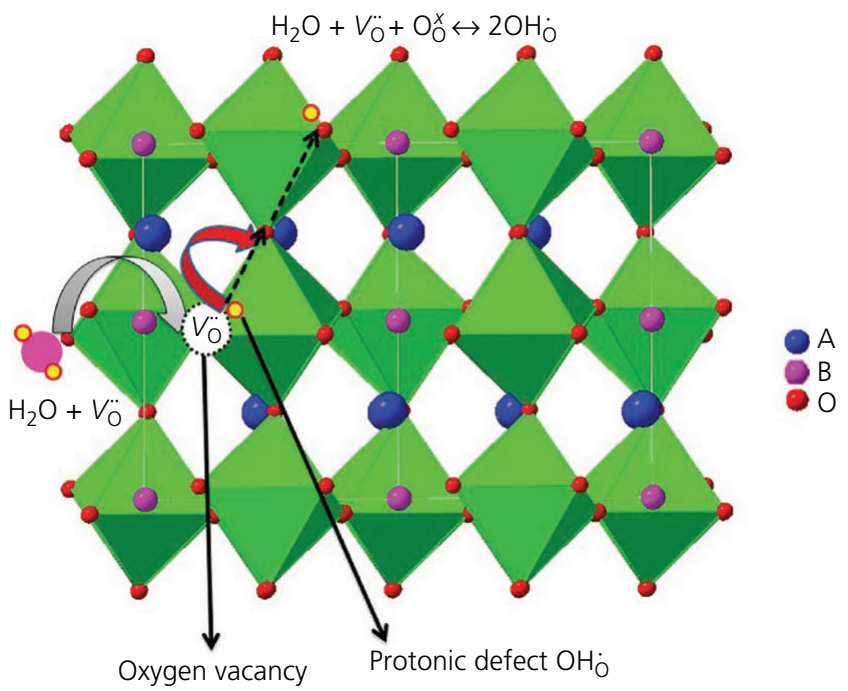

Figure 2. Proton conduction mechanism in perovskite oxide

2. $\mathrm{H}_{2} \mathrm{O}+V_{\mathrm{O}}^{*}+\mathrm{O}_{\mathrm{O}}^{x} \leftrightarrow 2 \mathrm{OH}_{\mathrm{O}}$

where $V_{\mathrm{O}}$ is the Kröger-Vink notation for an oxygen vacancy; $\mathrm{O}_{\mathrm{O}}^{x}$ is an oxide ion; and $\mathrm{OH}_{\mathrm{O}}$ is a proton attached to an oxide ion. The protons thus introduced may move around in the crystal by jumping from one oxygen atom to another.

Under reducing conditions (low oxygen partial pressure), the sample may lose oxygen and form electrons as given in the equation below

3. $\mathrm{O}_{\mathrm{O}}^{x}=\frac{1}{2} \mathrm{O}_{2}(g)+V_{\mathrm{O}}^{*}+2 e^{\prime}$

The oxidising conditions (high oxygen partial pressure) result in the formation of electronic holes $(h)$

4. $\frac{1}{2} \mathrm{O}_{2}(g)+V_{\mathrm{O}}^{*}=\mathrm{O}_{\mathrm{O}}^{x}+h$

\section{Oxide-ion-conducting perovskites}

Oxide-ion conductors have been widely used in fuel cells, oxygen sensors, oxygen pumps and oxygen-permeable membrane catalysts. ${ }^{35-38}$ Most of these applications require a high temperature to achieve high oxygen flux for efficient operation. Perovskite is one class of material exhibiting high oxide-ion conduction. ${ }^{35}$ To be an oxide-ion conductor, the essential feature is the presence of oxygen vacancies. Doping is usually performed by substituting a lower-valence cation into the lattice, with the added effect of introducing oxygen vacancies to maintain overall charge neutrality. ${ }^{39}$ These oxygen vacancies supply the equivalent 
sites, allowing the oxygen ions to migrate, thus facilitating ionic conductivity. The oxide-ion conduction mechanism in a nonstoichiometric perovskite with a double-perovskite structure (e.g. $\left.\mathrm{Ba}_{4} \mathrm{Ca}_{2} \mathrm{Nb}_{2} \mathrm{O}_{11}\right)$ is described in Figure 3 .

At a high temperature, due to the lattice vibrations and chemical potential gradient, oxide ions move to the nearby oxygen vacancies. Further, the vacancy created by the movement of one oxide ion will be occupied by another neighbouring oxide ion. This movement is a result of thermally activated hopping of the oxide ions, moving from one crystal lattice site to a neighbouring lattice site, with a superimposed drift in the direction of the electric field. The oxygen ions are the largest components of the lattice, with an ionic radius of $1.4 \AA .^{39}$ It is expected that smallerionic-radius metals have appreciable mobility in the lattice with enhanced conductivity.

Well-known oxide-ion conductors are yttria-stabilised zirconia (YSZ), cerium gadolinium oxide (CGO), $\mathrm{La}_{0.9} \mathrm{Sr}_{0.1} \mathrm{Ga}_{0.8} \mathrm{Mg}_{0.2} \mathrm{O}_{2 \cdot 85}$ (LSGM), $\mathrm{La}_{10}\left(\mathrm{SiO}_{4}\right)_{6} \mathrm{O}_{3}$ (silicon (Si)-apatite), $\mathrm{La}_{2} \mathrm{Mo}_{2} \mathrm{O}_{9}$ and $\mathrm{Bi}_{2} \mathrm{~V}_{1.8} \mathrm{Cu}_{0.1} \mathrm{O}_{5 \cdot 35}{ }^{40,41}$ These oxides exhibit higher oxide-ion conductivity on the order of $0.1 \mathrm{~S} / \mathrm{cm}$. YSZ and CGO are commercially available oxide-ion conductors used for SOFC electrolyte material. LSGM is a perovskite-based oxide-ion conductor exhibiting higher ionic conductivity than the fluorite YSZ. In terms of activation energy, mixed conducting materials exhibit lower activation energy $(\sim 0.25 \mathrm{eV})$, whereas oxide-ion conductivity requires higher activation energy $(\sim 0 \cdot 6-1 \cdot 2 \mathrm{eV})$. $^{42}$

\section{BCN proton-oxide-ion conductor}

Complex perovskites of type $\mathrm{A}_{3}\left(\mathrm{~B}_{1+x} \mathrm{~B}^{\prime}{ }_{2-x}\right) \mathrm{O}_{9-3 x / 2}$, where $\mathrm{A}$ and $\mathrm{B}=$ alkaline-earth metals and $\mathrm{B}^{\prime}=$ niobium or tantalum $(0<x \leq 0.5)$

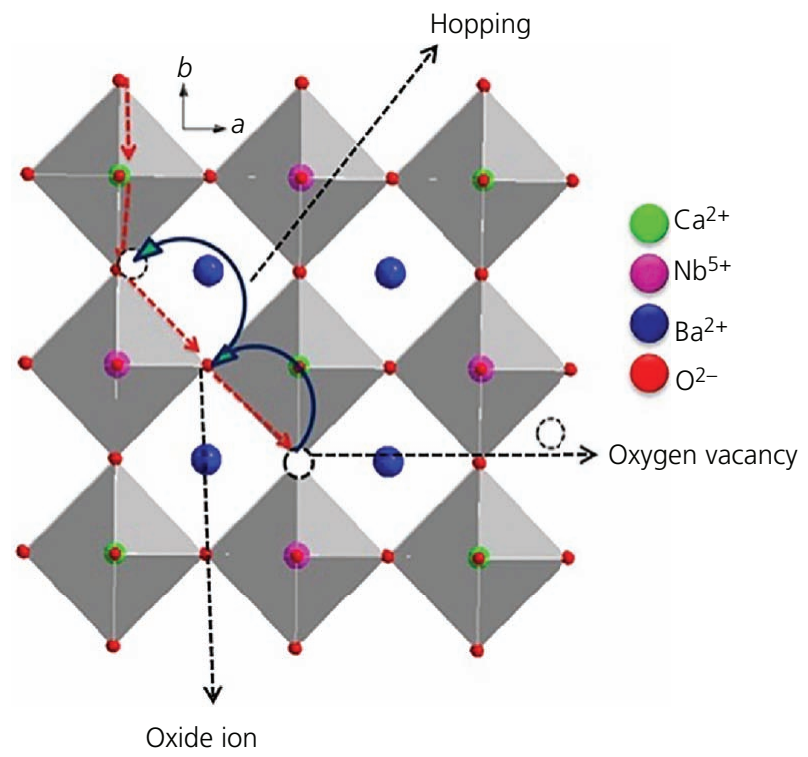

Figure 3. Oxide-ion conduction in non-stoichiometric perovskite oxide exhibit high oxide-ion conductivity in dry atmospheres $\left(>400^{\circ} \mathrm{C}\right.$, higher temperatures) and proton conductivity in hydrated atmospheres $\left(<400^{\circ} \mathrm{C}\right.$, lower temperatures $) .^{22,23,43}$ In recent years, such ceramic oxides have been extensively studied due to their high proton conductivity $\left(5.3 \times 10^{-3} \mathrm{~S} / \mathrm{cm}\right)$ at intermediate temperatures $\left(500-750^{\circ} \mathrm{C}\right)$ with a low activation energy of $\sim 0.54 \mathrm{eV}^{44}$ These intermediate-temperature proton conductors are widely used in diverse applications. ${ }^{8,45,46}$ Among different types of protonconducting ceramics, cerates are found to exhibit the highest proton conductivity of $1.0 \times 10^{-2} \mathrm{~S} / \mathrm{cm}^{44,47,48}$ However, cerates readily decompose in carbon dioxide or humid atmospheres and thus exhibit thermodynamic instability. ${ }^{44}$ Later, cerium (Ce) partially replaced zirconium $(\mathrm{Zr})$ ions to improve their stability. Zirconium substitution in cerates provided good stability, but their total conductivity was greatly reduced. ${ }^{49,50}$ In order to improve the stability and conductivity of proton conductors, many research groups started working on other alternate oxides. Among many ceramic oxides, the cation off-stoichiometric complex perovskite $\mathrm{Ba}_{3} \mathrm{Ca}_{1 \cdot 18} \mathrm{Nb}_{1 \cdot 82} \mathrm{O}_{9-\delta}$ (BCN 18) exhibits a high transport number close to unity in reducing atmospheres ${ }^{51}$ with proton conductivity of around $0 \cdot 1 \mathrm{~S} / \mathrm{cm}$ in a water atmosphere. BCN 18 also exhibits high structural and chemical stability against carbon dioxide and humidified atmospheres. ${ }^{52} \quad \mathrm{Ba}_{3} \mathrm{Ca}_{1 \cdot 18} \mathrm{Nb}_{1 \cdot 82} \mathrm{O}_{9-\delta}$ was originally derived from $\mathrm{Ba}_{3} \mathrm{CaNb}_{2} \mathrm{O}_{9}$, which is a 1:2-ordered perovskite type. ${ }^{23} \mathrm{Ba}_{3} \mathrm{CaNb}_{2} \mathrm{O}_{9}$ is an insulator with no structural oxygen vacancies with $\mathrm{B}$-site ordering blocking the movement of the ionic defects. By making the calcium ion $\left(\mathrm{Ca}^{2+}\right)$ off-stoichiometry $\left(\mathrm{Ba}_{3} \mathrm{Ca}_{1 \cdot 18} \mathrm{Nb}_{1.82} \mathrm{O}_{9-\delta}\right)$, oxygen vacancies are created, which facilitates the proton/oxide-ion conductivity. ${ }^{44} \mathrm{BCN} 18$ with modified B-site ordering is mostly synthesised by using the solidstate method. Few researchers studied the electrical properties of $\mathrm{Ba}_{3} \mathrm{Ca}_{1 \cdot 18} \mathrm{Nb}_{1 \cdot 82} \mathrm{O}_{9-\delta}$ prepared by using the combustion method. ${ }^{53}$ It was revealed that dopants in the niobium site could improve the proton conductivity without sacrificing chemical stability. ${ }^{54}$ Oxygen-deficient $\mathrm{Ba}_{4} \mathrm{Ca}_{2} \mathrm{Nb}_{2} \mathrm{O}_{11}$, a 1:1-ordered compound, nominally has a higher concentration of oxygen vacancies than $\mathrm{BCN} 18{ }^{29}$ The proton and oxide-ion conductivity of $\mathrm{Ba}_{4} \mathrm{Ca}_{2} \mathrm{Nb}_{2} \mathrm{O}_{11}$ was studied and compared with that of $\mathrm{Ba}_{3} \mathrm{Ca}_{1 \cdot 18} \mathrm{Nb}_{1.82} \mathrm{O}_{9-\delta}$. It is observed that, even though a higher concentration of oxygen vacancies is present in $\mathrm{Ba}_{4} \mathrm{Ca}_{2} \mathrm{Nb}_{2} \mathrm{O}_{11}$, it does not show better results because the increasing concentration of oxygen vacancies reduced the oxygen ion mobility. ${ }^{29}$ It is observed that $\mathrm{Ba}_{4} \mathrm{Ca}_{2} \mathrm{Nb}_{2} \mathrm{O}_{11}$ in dry air retains its cubic crystal structure with space group $F m \overline{3} m$ having structural oxygen vacancies. However, when it is annealed in wet air, its crystal structure changes to monoclinic with space group $C 2 / m$ due to water incorporation in vacancies. ${ }^{26,29}$ The change in the ratio between barium and calcium greatly influences the electrical properties of perovskite $\left(\mathrm{Ba}_{1-x} \mathrm{Ca}_{x}\right)_{6} \mathrm{Nb}_{2} \mathrm{O}_{11}(0.23 \leq x \leq 0.47)$ solid solutions. ${ }^{55}$ It is also observed that the increase in barium content decreases oxide-ion and proton conductivity. ${ }^{55}$ As said earlier, doping in the niobium site has proven to enhance the electrical properties. ${ }^{54}$ Therefore, research has been focused towards doping different elements in the niobium site. Because of doped non-metallic phosphate in the proton conductor $\mathrm{Ba}_{4} \mathrm{Ca}_{2} \mathrm{Nb}_{2} \mathrm{O}_{11}$, it is found that oxoanion 
substitution enhances the chemical stability in a carbon dioxide atmosphere. $^{56}$ Doping new elements to increase conductivity should not affect chemical stability, which in turn affects performance. Several elements such as tantalum, titanium (Ti), iron, manganese $(\mathrm{Mn})$, cobalt $(\mathrm{Co})$ and potassium $(\mathrm{K})$ are doped in the proton conductor $\mathrm{Ba}_{3} \mathrm{Ca}_{1+x} \mathrm{Nb}_{2-x} \mathrm{O}_{9-\delta}(\mathrm{BCN})$ to enhance the number of oxygen vacancies and also to maintain chemical stability. ${ }^{57-60}$ The effect of potassium on the electrical properties of 1:1-ordered BCN proton conductor was studied, and it was found that better conductivity and chemical stability can be achieved when $25 \%$ of the barium sites are replaced by potassium ions. ${ }^{61}$ The effects of cerium and yttrium (Y) doping on the calcium and niobium ions in complex perovskite $\mathrm{Ba}_{3} \mathrm{Ca}_{1 \cdot 18} \mathrm{Nb}_{1 \cdot 82} \mathrm{O}_{9-\delta}$ proton conductor was also studied. ${ }^{44,46}$ Such doping demonstrated new directions in the development of new materials for intermediatetemperature proton conductors with high conductivity and good stability. The doped compositions of $\mathrm{BCN}$ perovskite and their conductivity values are listed in Table 1 . It is observed in the table that doping in $\mathrm{BCN}$ perovskite improves both conductivity range and stability, making it even more suitable for SOFC devices.

\section{Role of nanoperovskites in SOFCs}

SOFCs have gained increasing attention over the past few decades because of their likely applications in lowering industrial pollutant emission and increasing energy efficiency. ${ }^{63-67}$ However, a number of problems, such as unsatisfactory redox stability, remain to be solved prior to the large-scale industrial application of the technology. Nanostructured materials have extensive applications in such devices due to their size-reduction properties. Perovskite materials synthesised as nanoperovskites with an increased surface area-to-volume ratio, which in turn increases the active electrode area, can be used in oxygen separation membranes, sensors, SOFCs and so on. The use of nanomaterials in SOFCs is directed towards $(a)$ lowering the temperature of operation of the cell (down to $300-400^{\circ} \mathrm{C}$ ), (b) retaining phase/thermal stability, (c) achieving the essential level of conductivity $(0 \cdot 1 \mathrm{~S} / \mathrm{cm})$, $(d)$ introducing tolerance to sulfur, $(e)$ avoiding carbon deposition on the anode when hydrocarbon fuels are used and so on. ${ }^{68,69}$

Table 1. Conductivity of BCN and doped BCN

\begin{tabular}{|c|c|}
\hline Composition & Conductivity: S/cm \\
\hline $\mathrm{Ba}_{3} \mathrm{Ca}_{1+x} \mathrm{Nb}_{2-x} \mathrm{O}_{9-\delta}$ & $5.5 \times 10^{-4}$ at $600^{\circ} \mathrm{C}(\text { air })^{24}$ \\
\hline $\mathrm{Ba}_{2}\left(\mathrm{Ca}_{0.9} \mathrm{Nb}_{0.66} \mathrm{Ta}_{0.55}\right) \mathrm{O}_{6-\delta}$ & $5.0 \times 10^{-4}$ at $400^{\circ} \mathrm{C}(\text { wet })^{57}$ \\
\hline $\mathrm{Ba}_{3} \mathrm{Ca}_{1.18} \mathrm{Nb}_{1.57} \mathrm{Ti}_{0.25} \mathrm{O}_{8.605}$ & $3.5 \times 10^{-4}$ at $400^{\circ} \mathrm{C}$ (wet $)^{58}$ \\
\hline $\mathrm{Ba}_{2} \mathrm{Ca}_{0.79} \mathrm{Co}_{0.5} \mathrm{Nb}_{0.71} \mathrm{O}_{6-\delta}$ & $3.7 \times 10^{-2}$ at $816^{\circ} \mathrm{C}(\text { air })^{59}$ \\
\hline $\mathrm{Ba}_{2} \mathrm{Ca}_{0.79} \mathrm{Mn}_{0.5} \mathrm{Nb}_{0.71} \mathrm{O}_{5.09}$ & $7.74 \times 10^{-4}$ at $600^{\circ} \mathrm{C}(\text { air })^{59}$ \\
\hline $\mathrm{Ba}_{2} \mathrm{Ca}_{0.67} \mathrm{Fe}_{0.33} \mathrm{NbO}_{5.66}$ & $7.82 \times 10^{-4}$ at $600^{\circ} \mathrm{C}(\text { air })^{59}$ \\
\hline $\mathrm{Ba}_{1.75} \mathrm{~K}_{1.25} \mathrm{CaNb}_{2} \mathrm{O}_{9-\delta}$ & $\begin{array}{l}1.0 \times 10^{-3} \text { at } 700^{\circ} \mathrm{C} \\
\left(\text { dry hydrogen gas }\left(\mathrm{H}_{2}\right)\right)^{60}\end{array}$ \\
\hline $\mathrm{Ba}_{4} \mathrm{~K}_{4} \mathrm{Ca}_{4} \mathrm{Nb}_{4} \mathrm{O}_{20}$ & $3.79 \times 10^{-5}$ at $800^{\circ} \mathrm{C}(\text { air })^{51}$ \\
\hline $\begin{array}{l}\mathrm{Ba}_{3} \mathrm{Ca}_{1.18} \mathrm{Nb}_{1.77} \mathrm{Ni}_{0.05} \mathrm{O}_{9-\delta} \\
(\mathrm{BCNNi})\end{array}$ & $2.6 \times 10^{-3}$ at $700^{\circ} \mathrm{C}$ (wet air) ${ }^{62}$ \\
\hline $\begin{array}{l}\mathrm{Ba}_{3} \mathrm{Ca}_{1.18} \mathrm{Nb}_{1.52} \mathrm{Y}_{0.3} \mathrm{O}_{9-\delta} \\
(\mathrm{BCNYO} \cdot 3 \text { ) }\end{array}$ & $5.3 \times 10^{-3}$ at $600^{\circ} \mathrm{C}$ (wet air) ${ }^{44}$ \\
\hline $\mathrm{Ba}_{3} \mathrm{Ca}_{1.18} \mathrm{Nb}_{1.62} \mathrm{Ce}_{0.2} \mathrm{O}_{9-\delta}$ & $\begin{array}{l}2.69 \times 10^{-3} \text { at } 550^{\circ} \mathrm{C} \\
\text { (wet hydrogen gas) }^{46}\end{array}$ \\
\hline
\end{tabular}

The surface area obtained from nanostructured materials is several times higher than that of bulk materials. This increases the triplephase boundary and enhances the electrochemical performance of SOFCs. ${ }^{70}$ The reduction in particle size is also expected to reduce the operating temperature, which is a major limitation ascribed to sintering processes. Overall, the use of nanomaterial layers reduces the working temperature with enhanced cell performance. Specifically, the major challenge with regard to the electrolyte layer of SOFCs is to make a thin layer of electrolyte without sacrificing structural integrity and other characteristics. The grain growth of nanostructured ionic conductors is also suppressed by adding another phase into an interparticle region. Such composite nanostructured electrolytes show prominent conductivity enhancement. ${ }^{71}$ With these advantages, nanoperovskites are expected to play an important role in the fabrication of novel SOFCs for clean energy generation.

\subsection{BCN for SOFCs and other applications}

As described earlier, $\mathrm{BCN}$ and doped $\mathrm{BCN}$ are used in a wide range of applications such as SOFCs, gas separation membranes and sensors. Since BCN 18 shows remarkable chemical stability in carbon dioxide and humid atmospheres, it can be used for practical applications, but its relatively low conductivity hinders its usage in certain applications. It is observed that doping cerium (IV) $\left(\mathrm{Ce}^{4+}\right)$ in $\mathrm{BCN} 18$ showed significant enhancement of electrical properties along with better chemical stability. ${ }^{46}$ Among compositions with different cerium dopant concentrations, the composition $\mathrm{Ba}_{3} \mathrm{Ca}_{1 \cdot 18} \mathrm{Nb}_{1.62} \mathrm{Ce}_{0.2} \mathrm{O}_{9-\delta}$ exhibited higher proton conductivity of $2.69 \times 10^{-3} \mathrm{~S} / \mathrm{cm}$ at $550^{\circ} \mathrm{C}$ and good stability in the intermediate-temperature range. Its thermal expansion coefficient is $14.73 \times 10^{-6} \mathrm{~K}^{-1}$ in air and $15.03 \times 10^{-6} \mathrm{~K}^{-1}$ in $5 \%$ hydrogen gas $\left.\left(\mathrm{H}_{2}\right)\right) .{ }^{46}$ An SOFC single cell was fabricated using a two-step sintering method using BCN 18 as electrolyte, and its performance was studied. ${ }^{72}$ The maximum power density obtained was about $106 \mathrm{~mW} / \mathrm{cm}^{2}$ at $750^{\circ} \mathrm{C}$ compared to earlier reported power densities. A maximum power density obtained using BCN 18 as electrolyte, prepared by using an in situ method, was $48 \mathrm{~mW} / \mathrm{cm}^{2}$ at $700{ }^{\circ} \mathrm{C} .{ }^{54}$ The effect of partial substitution of niobium ions by yttrium ions $\left(\mathrm{Ba}_{3} \mathrm{Ca}_{1 \cdot 18} \mathrm{Nb}_{1.52} \mathrm{Y}_{0.3} \mathrm{O}_{9-\delta}\right)$ showed a proton conductivity value of $5.3 \times 10^{-3} \mathrm{~S} / \mathrm{cm}$ at $600^{\circ} \mathrm{C}$ with cell power output of $103 \mathrm{~mW} / \mathrm{cm}^{2}$ at $750{ }^{\circ} \mathrm{C} .{ }^{44}$ The power outputs of devices fabricated using doped and undoped $\mathrm{BCN}$ as electrolyte are listed in Table 2. It can be noticed from the table that the highest power output reported so far was obtained when using BCN 18 as electrolyte and nickel- $\mathrm{Ba}_{3} \mathrm{Ca}_{1 \cdot 18} \mathrm{Nb}_{1 \cdot 82-x} \mathrm{Y}_{x} \mathrm{O}_{9}$ $(\mathrm{BCZYYb}) / \mathrm{BaCo}_{0.7} \mathrm{Fe}_{0.2} \mathrm{Nb}_{0.1} \mathrm{O}_{3-\delta}(\mathrm{BCFN})$ as electrodes.

The crystal structure of perovskite materials, when synthesised as nanoperovskites, varies based on the type of dopant and arrangement of defects. ${ }^{75}$ The defects formed on the surface play an essential role in the tuning of many properties other than proton and oxide-ion conductivity. These properties provide a wider scope of applications other than in SOFCs, such as in gas sensors; piezoelectric, ferroelectric, dielectric, optical and pyroelectric devices; thermistors; multilayer ceramic capacitors; 
Table 2. Conductivity and SOFC studies of BCN and doped BCN perovskites

\begin{tabular}{|c|c|c|c|c|c|}
\hline Electrolyte & Electrolyte thickness: $\mu \mathrm{m}$ & Anode & Cathode & Power output: $\mathrm{mW} / \mathrm{cm}^{2}$ & Conductivity $(\sigma):$ S/cm \\
\hline $\mathrm{BCN}^{73}$ & 1000 & Platinum (Pt) & Platinum & 0.4 & $1.51 \times 10^{-3}$ \\
\hline $\mathrm{BCN}^{54}$ & 15 & $\mathrm{Ni}-\mathrm{BCN}$ & LSF & 48 & $1.51 \times 10^{-3}$ \\
\hline $\mathrm{BCN}^{74}$ & 25 & $\mathrm{Ni}-\mathrm{BCN}$ & BCFN & 46 & $1.51 \times 10^{-3}$ \\
\hline $\mathrm{BCN}^{74}$ & 25 & $\mathrm{Ni}-\mathrm{BCZYYb}$ & BCFN & 97 & $1.51 \times 10^{-3}$ (wet hydrogen gas) \\
\hline BCN $18^{46}$ & 25 & $\mathrm{Ni}-\mathrm{BCZYYb}$ & BCFN & 106 & $2 \times 10^{-3}$ (air) \\
\hline $\mathrm{BCNNi}{ }^{62}$ & 45 & $\mathrm{Ni}-\mathrm{BCNNi}$ & PBCO & 84 & $4.59 \times 10^{-3}$ \\
\hline BCNYO $\cdot 3^{44}$ & Not mentioned & $\mathrm{Ni}-\mathrm{BCZYYb}$ & Platinum/air & 103 & $5.3 \times 10^{-3}$ \\
\hline
\end{tabular}

LSF, $\mathrm{La}_{0.7} \mathrm{Sr}_{0.3} \mathrm{FeO}_{3-\sigma} ; \mathrm{PBCO}, \mathrm{PrBaCO}_{2} \mathrm{O}_{5+\delta}$

pressure sensors; and hydrogen sensors. ${ }^{76-78}$ Recent studies stated that the negligible release of thorium in seawater from Greek bauxite residue is found due to its incorporation into an insoluble perovskite-type phase with major composition of $\mathrm{Ca}_{0.8} \mathrm{Na}_{0.2} \mathrm{TiO}_{3}$ and crystallites observed at the nanoscale. ${ }^{79}$ However, when nanoperovskite is used as sintered ceramic, the resistance to ion migration offered by the grain boundaries is one of the major challenges which need to be addressed during device fabrication.

\section{Conclusion}

In this review, the essential role of oxygen vacancies in perovskite oxides with associated proton and oxide-ion-conducting properties is discussed. Cation ordering in $\mathrm{BCN}$ perovskite decides the nature and the number of oxygen vacancies, which are also the sources of protonic defects. Doped and undoped BCN, with 1:1-ordered B-site cation sublattice, behave as both proton (wet atmosphere-low temperature) and oxide-ion conductors (dry atmosphere-high temperature). The role of $\mathrm{BCN}$ in SOFCs is discussed in detail. Using suitable dopants in $\mathrm{BCN}$ proton conductors can widen their applications in many other devices for energy applications.

\section{Acknowledgements}

The authors acknowledge the Naval Research Board and University Grants Commission-Rajiv Gandhi National Fellowship fellowship for financial support and the PSG Institute of Advanced studies and Naval Materials Research Laboratory for their infrastructure and intellectual support.

\section{REFERENCES}

1. Faro M, La Rosa D, Antonucci V and Arico AS (2009) Intermediate temperature solid oxide fuel cell electrolytes. Journal of the Indian Institute of Science 89(4): 363-380.

2. Chandran PR and Arjunan TV (2015) A review of materials used for solid oxide fuel cell. International Journal of ChemTech Research 7(1): 488-497.

3. Cheng Z and Lin J (2010) Layered organic-inorganic hybrid perovskites: structure, optical properties, film preparation, patterning and templating engineering. CrystEngComm 12(10): 2646-2662.

4. West AR (2006) Inorganic functional materials: optimization of properties by structural and compositional control. The Chemical Record 6(4): 206-216.

5. Ruzmetov D, Seo Y, Belenky LJ et al. (2005) Magnetic perovskite nanostructures. Advanced Materials 17(23): 2869-2872.

6. Voorhoeve RJH, Johnson DW, Remeika JP and Gallagher PK (1977) Perovskite oxides: materials science in catalysis. Science 195(4281): $827-833$.
7. Takeda Y, Imanishi N, Kanno R et al. (1992) Oxide ion conductivity in perovskite type $\mathrm{Sr}_{2} \mathrm{ScAlO}_{5}$ and related compounds. Solid State Ionics 53-56(Part 2): 748-753.

8. Kreuer KD, Adams S, Münch W, Fuchs A, Klock U and Maier J (2001) Proton conducting alkaline earth zirconates and titanates for high drain electrochemical applications. Solid State Ionics 145(1-4): 295-306.

9. Muller O and Roy R (1975) The major ternary structural families. Crystal Research and Technology 10(7): K86.

10. Iwahara H (2009) Ionic conduction in perovskite-type compounds. In Perovskite Oxide for Solid Oxide Fuel Cells (Ishihara T (ed.)). Springer, Boston, MA, USA, pp. 45-63.

11. Vyshatko NP, Kharton V, Shaula AL, Naumovich EN and Marques FMB (2003) Structural characterization of mixed conducting perovskites La $(\mathrm{Ga}, \mathrm{M}) \mathrm{O}_{3-\delta}(\mathrm{M}=\mathrm{Mn}, \mathrm{Fe}, \mathrm{Co}, \mathrm{Ni})$. Materials Research Bulletin 38(2): 185-193.

12. Inoue IH (2005) Electrostatic carrier doping to perovskite transitionmetal oxides. Semiconductor Science Technology 20(4): S112-S120.

13. Irvine JTS (2009) Perovskite oxide anodes for SOFCs. In Perovskite Oxide for Solid Oxide Fuel Cells (Ishihara T (ed.)). Springer, Boston, MA, USA, pp. 167-182.

14. Attfield JP (2002) 'A' cation control of perovskite properties. Crystal Engineering 5(3-4): 427-438.

15. Reichmann M, Geffroy PM, Fouletier J, Richet $\mathrm{N}$ and Chartier T (2014) Effect of cation substitution in the A site on the oxygen semipermeation flux in $\mathrm{La}_{0.5} \mathrm{~A}_{0.5} \mathrm{Fe}_{0.7} \mathrm{Ga}_{0.3} \mathrm{O}_{3-\delta}$ and $\mathrm{La}_{0.5} \mathrm{~A}_{0.5} \mathrm{Fe}_{0.7} \mathrm{Co}_{0.3} \mathrm{O}_{3-\delta}$ dense perovskite membranes with $\mathrm{A}=\mathrm{Ca}, \mathrm{Sr}$ and $\mathrm{Ba}$ (part I). Journal of Power Sources 261: 175-183.

16. Pecchi G, Jiliberto MG, Delgado EJ, Cadus LE and Fierro JLG (2011) Effect of B-site cation on the catalytic activity of $\mathrm{La}_{1-x} \mathrm{Ca}_{x} \mathrm{BO}_{3}(\mathrm{~B}=$ $\mathrm{Fe}, \mathrm{Ni}$ ) perovskite-type oxides for toluene combustion. Journal of Chemical Technology \& Biotechnology 86(8): 1067-1073.

17. Pena MA and Fierro JLG (2001) Chemical structures and performance of perovskite oxides. Chemical Reviews 101(7): 1981-2017.

18. Su C, Wang W, Chen $Y$ et al. (2015) $\mathrm{SrCo}_{0.9} \mathrm{Ti}_{0.1} \mathrm{O}_{3-\delta}$ as a new electrocatalyst for the oxygen evolution reaction in alkaline electrolyte with stable performance. ACS Applied Materials \& Interfaces 7(32): 17663-17670

19. Zhang Z, Chen Y, Tade MO et al. (2014) Tin-doped perovskite mixed conducting membrane for efficient air separation. Journal of Materials Chemistry A 2(25): 9666-9674.

20. Jung KN, Jung JH, Im WB et al. (2013) Doped lanthanum nickelates with a layered perovskite structure as bifunctional cathode catalysts for rechargeable metal-air batteries. ACS Applied Materials \& Interfaces 5(20): 9902-9907.

21. Shao $Z$ and Haile SM (2004) A high-performance cathode for the next generation of solid-oxide fuel cells. Nature 431(7005): 170-173.

22. Du $Y$ and Nowick AS (1995) Structural transitions and proton conduction in nonstoichiometric $\mathrm{A}_{3} \mathrm{~B}^{\prime} \mathrm{B}^{\prime \prime} \mathrm{O}_{9}$ perovskite-type oxides. Journal of the American Ceramic Society 78(11): 3033-3039.

23. Nowick AS, Du Y and Liang KC (1999) Some factors that determine proton conductivity in nonstoichiometric complex perovskites. Solid State Ionics 125(1-4): 303-311. 
24. Norby T (1999) Solid-state protonic conductors: principles, properties, progress and prospects. Solid State Ionics 125(1-4): 1-11.

25. Stambouli AB and Traversa E (2002) Solid oxide fuel cells (SOFCs): a review of an environmentally clean and efficient source of energy. Renewable and Sustainable Energy Reviews 6(5): 433-455.

26. Ashok A, Kochetova N, Norby T and Oslen A (2008) Structural study of the perovskite system $\mathrm{Ba}_{6-y} \mathrm{Ca}_{y} \mathrm{Nb}_{2} \mathrm{O}_{11}$ hydrated to proton conducting $\mathrm{Ba}_{6-y} \mathrm{Ca}_{y} \mathrm{Nb}_{2} \mathrm{O}_{10}(\mathrm{OH})_{2}$. Solid State Ionics 179(33-34): 1858-1866.

27. Galasso FS (1990) Perovskites and High $T_{c}$ Superconductors. Gordon $\&$ Breach Science, New York, NY, USA.

28. Schober T and Friedrich J (2000) The mixed perovskites $\mathrm{BaCa}_{(1+x) / 3}$ $\mathrm{Nb}_{(2-x) / 3} \mathrm{O}_{3-x / 2}(x=0 \ldots 0.18)$ : proton uptake. Solid State Ionics 136-137: 161-165.

29. Animitsa I, Neiman A, Kotchetova N, Melekh B and Sharafutdinov A (2003) Proton and oxygen-ion conductivity of $\mathrm{Ba}_{4} \mathrm{Ca}_{2} \mathrm{Nb}_{2} \mathrm{O}_{11}$. Solid State Ionics 162-163: 63-71.

30. Iwahara H, Esaka T, Uchida H and Maeda N (1981) Proton conduction in sintered oxides and its application to steam electrolysis for hydrogen production. Solid State Ionics 3-4: 359-363.

31. Yajima T, Suzuki H, Yogo T and Iwahara H (1992) Protonic conduction in $\mathrm{SrZrO}_{3}$-based oxides. Solid State Ionics 51(1-2): 101-107.

32. Iwahara H (1996) Proton conducting ceramics and their applications. Solid State Ionics 86-88(Part 1): 9-15.

33. Katahira K, Kohchi Y, Shimura T and Iwahara H (2000) Protonic conduction in $\mathrm{Zr}$-substituted $\mathrm{BaCeO}_{3}$. Solid State Ionics 138(1-2): 91-98.

34. Kreuer KD (2003) Proton-conducting oxides. Annual Review on Material Research 33: 333-359.

35. Kendall KR, Navas C, Thomas JK and zur Loye HC (1999) Recent developments in perovskite-based oxide ion conductors. Solid State Ionics 82(3-4): 215-223.

36. Steele BCH (1992) Oxygen ion conductors and their technological applications. Materials Science and Engineering: B 13(2): 79-87.

37. Minh NQ (1993) Ceramic fuel cell. Journal of the American Ceramic Society 76(3): 563-588.

38. Di Cosimo R, Burrington JD and Grasselli RK (1986) Oxidative dehydrodimerization of propylene over a $\mathrm{Bi}_{2} \mathrm{O}_{3} \cdot \mathrm{La}_{2} \mathrm{O}_{2}$ oxide ionconductive catalyst. Journal of Catalysis 102(10): 234-239.

39. Skinner SJ and Kilner JA (2003) Oxygen ion conductors. Materials Today 6(3): 30-37.

40. Zhou N, Chen G, Zhang HJ and Zhou C (2009) Synthesis and transport properties of $\mathrm{La}_{2} \mathrm{NiO}_{4}$. Physica B: Condensed Matter 404(21): 4150-4154.

41. Punn R, Feteira AM, Sinclair DC and Greaves C (2006) Enhanced oxide ion conductivity in stabilized $\delta-\mathrm{Bi}_{2} \mathrm{O}_{3}$. Journal of the American Chemical Society 128(48): 15386-15387.

42. Caetano E, de Souza C and Muccillo R (2010) Properties and applications of perovskite proton conductors. Materials Research 13(3): 385-394.

43. Liang KC, Du Y and Nowick AS (1994) Fast high-temperature proton transport in nonstoichiometric mixed perovskites. Solid State Ionics 69(2): 117-120.

44. Wang $S$, Cheng Y, Fang S et al. (2014) Novel chemically stable $\mathrm{Ba}_{3} \mathrm{Ca}_{1.18} \mathrm{Nb}_{1.82-x} \mathrm{Y}_{x} \mathrm{O}_{9-\delta}$ proton conductor: improved proton conductivity through tailored cation ordering. Chemistry of Materials 26(6): 2021-2029.

45. Zhao F, Liu Q, Wang S, Brinkman K and Chen F (2010) Synthesis and characterisation of $\mathrm{BaIn}_{0.3-x} \mathrm{Y}_{x} \mathrm{Ce}_{0.7} \mathrm{O}_{3-\delta}(x=0,0.1,0.2,0.3)$ proton conductors. International Journal of Hydrogen Energy 35(9): 4258-4263.

46. Wang S, Zhao F, Zhang L, Brinkman K and Chen F (2011) Doping effects on complex perovskite $\mathrm{Ba}_{3} \mathrm{Ca}_{1.18} \mathrm{Nb}_{1.82} \mathrm{O}_{9-\delta}$ intermediate temperature proton conductor. Journal of Power Sources 196(19): 7917-7923.

47. Zhao F, Wang S, Dixon L and Chen F (2011) Novel $\mathrm{BaCe}_{0.7} \mathrm{In}_{0.2} \mathrm{Yb}_{0.1} \mathrm{O}_{3-\delta}$ proton conductor as electrolyte for intermediate temperature solid oxide fuel cells. Journal of Power Sources 196(18): 7500-7504.

48. Amsif M, Marrero-Lopez D, Ruiz-Morales JC et al. (2011) Influence of rare-earth doping on the microstructure and conductivity of $\mathrm{BaCe}_{0.9} \mathrm{Ln}_{0.1} \mathrm{O}_{3-\delta}$ proton conductors. Journal of Power Sources 196(7): 3461-3469.

49. Azad A and Irvine JT (2007) Synthesis, chemical stability and proton conductivity of the perovksites $\mathrm{Ba}(\mathrm{Ce}, \mathrm{Zr})_{1-x} \mathrm{Sc}_{x} \mathrm{O}_{3-\delta}$. Solid State Ionics 178(7-10): 635-640.

50. Barison S, Battagliarin M, Cavallin T et al. (2008) High conductivity and chemical stability of $\mathrm{BaCe}_{1-x-y} \mathrm{Zr}_{x} \mathrm{Y}_{y} \mathrm{O}_{3-\delta}$ proton conductors prepared by a sol-gel method. Journal of Materials Chemistry 18(42): $5120-5128$

51. Nowick AS and Du Y (1995) High-temperature protonic conductors with perovskite-related structures. Solid State Ionics 77: 137-146.

52. Du Y and Nowick AS (1996) Galvanic cell measurements on a fast proton conducting complex perovskite electrolyte. Solid State Ionics 91(1-2): 85-91.

53. Bei $L$ and Traversa E (2013) Electrical properties of $\mathrm{Ba}_{3} \mathrm{Ca}_{1.18} \mathrm{Nb}_{1.82} \mathrm{O}_{9-\delta}$ proton-conducting electrolyte prepared by a combustion method. ECS Transactions 57(1): 1069-1075.

54. Bi L, Zhang S, Fang S et al. (2008) In situ fabrication of a supported $\mathrm{Ba}_{3} \mathrm{Ca}_{1.18} \mathrm{Nb}_{1.82} \mathrm{O}_{9-\delta}$ membrane electrolyte for a proton-conducting SOFC. Journal of the American Ceramic Society 91(11): 3806-3809.

55. Kochetova NA, Animitsa IE and Neiman AY (2009) The synthesis and properties of solid solutions based on $\mathrm{Ba}_{4} \mathrm{Ca}_{2} \mathrm{Nb}_{2} \mathrm{O}_{11}$. Russian Journal of Physical Chemistry A 83(2): 203-208.

56. Belova KG, Obrubova AV and Animitsa IE (2017) Effect of phosphate doping on electric properties and chemical stability of $\mathrm{Ba}_{4} \mathrm{Ca}_{2} \mathrm{Nb}_{2} \mathrm{O}_{11}$ protonic conductor. Russian Journal of Electrochemistry 53(7): 761-768.

57. Bhella SS and Thangadurai V (2009) Synthesis and characterization of carbon dioxide and boiling water stable proton conducting double perovskite-type metal oxides. Journal of Power Sources 186(2): 311-319.

58. Trinh TT and Thangadurai V (2010) Effect of Ti substitution for $\mathrm{Nb}$ in double perovskite-type $\mathrm{Ba}_{3} \mathrm{CaNb}_{2} \mathrm{O}_{9}$ on chemical stability and electrical conductivity. Electrochimica Acta 56(1): 227-234.

59. Kan WH, Roushanafshar M, Vincent A et al. (2013) Effect of substitution of B-sites by $\mathrm{Mn}, \mathrm{Fe}$ and $\mathrm{Co}$ in double perovskite-type $\mathrm{Ba}_{3} \mathrm{CaNb}_{2} \mathrm{O}_{9}$ on structure and electrical properties. RSC Advances 3(45): 23824-23832.

60. Bhella SS and Thangadurai $V$ (2011) Investigations on the thermochemical stability and electrical conductivity of $\mathrm{K}$-doped $\mathrm{Ba}_{3-x} \mathrm{~K}_{x}$ $\mathrm{CaNb}_{2} \mathrm{O}_{9-\delta}(x=0.5,0.75,1,1.25)$. Solid State Ionics 192(1): 229-234.

61. Kavitha K, Vijayaraghavan T, Kumbhar C, Ojha PK and Ashok A (2016) Structural and conductivity properties of $\mathrm{K}$ doped $\mathrm{Ba}_{4} \mathrm{Ca}_{2} \mathrm{Nb}_{2} \mathrm{O}_{11}(\mathrm{BCN})$ complex perovskite for energy applications. Journal of Alloys and Compounds 686: 930-937.

62. Zhua Z, Guoa E, Weia Z and Wang H (2018) Tailoring $\mathrm{Ba}_{3} \mathrm{Ca}_{1.18} \mathrm{Nb}_{1.82} \mathrm{O}_{9-\delta}$ with $\mathrm{NiO}$ as electrolyte for proton-conducting solid oxide fuel cells. Journal of Power Sources 373: 132-138.

63. Fowler DE, Haag J, Boland C et al. (2014) Stable, low polarization resistance solid oxide fuel cell anodes: $\mathrm{La}_{1-x} \mathrm{Sr}_{x} \mathrm{Cr}_{1-x} \mathrm{Fe}_{x} \mathrm{O}_{3-\delta}(x=$ 0.2-0.67). Chemistry of Materials 26(10): 3113-3120.

64. Chen M, Paulson S, Thangadurai V and Birss V (2013) Sr-rich chromium ferrites as symmetrical SOFC electrodes. Journal of Power Sources 236: 68-79.

65. Wachsman ED and Lee KT (2011) Lowering the temperature of solid oxide fuel cells. Science 334(6058): 935-939.

66. Cowin PI, Petit CTG, Lan R, Irvine JTS and Tao S (2011) Recent progress in the development of anode materials for solid oxide fuel cells. Advanced Energy Materials 1(3): 314-332.

67. Sun Y, Li J, Zeng Y et al. (2015) A-site deficient perovskite: the parent for in situ exsolution of highly active, regenerable nano- 
particles as SOFC anodes. Journal of Materials Chemistry A 3(20): 11048-11056.

68. Dhathathreyan KS, Rajalakshmi N and Balaji R (2017) Nanomaterials for fuel cell technology. In Nanotechnology for Energy Sustainability, 1st edn. (Raj B, Van de Voorde M and Mahajan Y (eds)). Wiley-VCH \& Co. KGaA, Weinheim, Germany, vol. 2, pp. 569-596.

69. Alzate-Restrepo V and Hill JM (2008) Effect of anodic polarization on carbon deposition on Ni/YSZ anodes exposed to methane. Applied Catalysis A: General 342(1-2): 49-55.

70. Pinedo R, Ruiz de Larramendi I, Ortiz-Vitoriano N, Jimenez de Aberasturi D and Rojo T (2013) Nanotechnology for improving solid oxide fuel cells. In Materials and Processes for Energy: Communicating Current Research and Technological Developments (Mendez-Vilas A (ed.)). Formatex Research Center, Badajoz, Spain, pp. 512-522.

71. Mahato N, Banerjee A, Gupta A, Omar S and Balani K (2015) Progress in material selection for solid oxide fuel cell technology: a review. Progress in Materials Science 72: 141-337.

72. Wang S, Zhang L, Yang Z et al. (2012) Two-step co-sintering method to fabricate anode-supported $\mathrm{Ba}_{3} \mathrm{Ca}_{1.18} \mathrm{Nb}_{1.82} \mathrm{O}_{9-\delta}$ proton-conducting solid oxide fuel cells. Journal of Power Sources 215: 221-226.

73. Gross B, Marion S, Lind S et al. (1999) Proton conducting $\mathrm{Ba}_{3} \mathrm{Ca}_{1.18} \mathrm{Nb}_{1.82} \mathrm{O}_{8.73}-\mathrm{H}_{2} \mathrm{O}$ : pressure-compositions isotherms in terms of Fermi-Dirac statistics, concentration and fuel-cell measurements, and impedance spectroscopy. Solid State Ionics 125(1-4): 107-117.

74. Viana HDL and Irvine JTS (2010) Characterisation of lower temperature sintered zinc-doped barium calcium niobate proton conducting electrolytes. Journal of Materials Chemistry 20(39): 8506-8511.

75. Madhavan B and Ashok A (2015) Review on nanoperovskites: materials, synthesis, and applications for proton and oxide ion conductivity. Ionics 21(3): 601-610.

76. Rao CNR, Kulkarni GU, Thomas PJ and Edwards PP (2002) Size dependent chemistry: properties of nanocrystals. Chemistry $-a$ European Journal 8(1): 28-35.

77. Das S, Chowdhury P, Gundu Rao TK, Das D and Bahadur D (2002) Influence of grain size and grain boundaries on the properties of $\mathrm{La}_{0.7} \mathrm{Sr}_{0.3} \mathrm{Co}_{x} \mathrm{Mn}_{1-x} \mathrm{O}_{3}$. Solid State Communications 121(12): 691-695.

78. Kameli $P$, Salamati $H$ and Aezami A (2008) Influence of grain size on magnetic and transport properties of polycrystalline $\mathrm{La}_{0.8} \mathrm{Sr}_{0.2} \mathrm{MnO}_{3}$ manganites. Journal of Alloys and Compounds 450(1-2): 7-11.

79. Gamaletsos PN, Godelitsas A, Kasama T et al. (2016) The role of nano-perovskite in the negligible thorium release in seawater from Greek bauxite residue (red mud). Scientific Reports 6: article 21737.

\section{How can you contribute?}

To discuss this paper, please submit up to 500 words to the journal office at journals@ice.org.uk. Your contribution will be forwarded to the author(s) for a reply and, if considered appropriate by the editor-in-chief, it will be published as a discussion in a future issue of the journal.

ICE Science journals rely entirely on contributions from the field of materials science and engineering. Information about how to submit your paper online is available at www.icevirtuallibrary.com/page/authors, where you will also find detailed author guidelines. 